Chirurgia (2021) 116: 368-373

No. 3, May-June

Copyright@ Celsius

http://dx.doi.org/10.21614/chirurgia.116.3.368

\title{
Rectal Neuroendocrine Tumour with an Aggressive Behaviour
}

\author{
Augustin Marian Marincas, Virgiliu Prunoiu*, Eugen Bratucu, Tudor Proca, Sinziana Ionescu \\ "Carol Davila" University of Medicine and Pharmacy, Bucharest, Romania \\ First Clinic of General Surgery and Oncology, "Prof. Al. Trestioreanu" Oncology Institute, Bucharest, Romania
}

*Corresponding author:

Virgiliu-Mihail Prunoiu, MD

General Surgery and Oncology Clinic I

"Prof. Al. Trestioreanu" Oncology

Institute, Bucharest, Romania

E-mail: virgiliuprunoiu@yahoo.com

\section{Rezumat}

\section{Tumoră neuroendocrină rectală cu evolutie agresivă}

Tumorile neuroendocrine sunt neoplasme epiteliale rare, cu caracteristici biologice tumorale specifice care pot pune probleme de diagnostic şi tratament şi care au în general un prognostic bun. În ultimele decenii incidența tumorilor neuroendocrine ale rectului a crescut datorită accesibilității colonoscopiei şi a introducerii programelor de screening pentru tumorile colorectale. Noi prezentăm cazul unui pacient în vârstă de 55 ani care s-a internat în data de 05.11.2018 pentru rectoragii debutate cu circa 6 luni înainte. La internare s-a constatat pacient cu stare generală bună, iar examanul clinic şi paraclinic au confirmat diagnosticul de tumoră malignă rectală stadiul IV. Examenul histopatologic nu a putut face distincția între un carcinom nediferențiat şi o tumoră neuroendocrină. Diagnosticul de tumoră neuroendocrină cu evoluție agresivă a fost precizat de examenul IHC (Ki67 75-80\%, G3). Datorită agresivității mari a tumorii pacientul a avut o evoluție rapidă spre agravare iar instalarea insuficienței hepatice nu a permis aplicarea tratamentului antitumoral sistemic. In concluzie putem spune că în tumorile neuroendocrine rectale stadiul bolii şi indicele Ki67 au o importantă valoare prognostică, iar în stabilirea diagnosticului şi a agresivității tumorii examenul IHC este obligatoriu. Deşi sunt în general tumori mici bine diferențiate, cu un prognostic destul de bun, există şi forme cu tumori de dimensiuni mari cu metastaze şi cu prognostic grav.

Cuvinte cheie: tumoră neuroendocrină, tumoră rectală 


\begin{abstract}
Neuroendocrine tumors are rare epithelial neoplasms with the specific biological characteristics which can make the diagnosis and treatment questionable, and, which in general, have a good prognosis. In recent decades, the incidence of rectal neuroendocrine tumors has increased due to the accessibility of colonoscopy and the introduction of screening programs for colorectal tumors. We present the case of a 55-year-old patient who presented for rectal bleeding started 6 months before. At the moment of the hospital admission, the general state of the patient was good, and the clinical and paraclinical examination confirmed the diagnosis of stage IV rectal tumor. The pathology examination could not distinguish between a non-differentiated carcinoma and a neuroendocrine tumor. The diagnosis of Rectal neuroendocrine tumor with an aggressive behaviour was established via immunohistochemistry (ki 67 index of $75-80 \%$, G3 grading). Due to the high aggressiveness of the tumor, the patient had a rapid evolution towards a severe state and the onset of liver failure did not allow the systemic anti-tumor treatment. In conclusion, we can state that in the case of rectal neuroendocrine tumors, the stage of the disease and the ki67 index have an important prognostic value, and it is crucial for both the diagnosis and tumor aggressiveness to have an immunohistochemical examination. Even though, in general, they are small well-differentiated tumors with a rather good prognosis, there are forms with tumors of greater dimensions and with metastases and severe prognosis.
\end{abstract}

Key words: neuroendocrine tumor, rectal tumor

\section{Introduction}

Neuroendocrine tumors of the digestive system represent a non-uniform group of tumors which derive from APUD cells (amine precursor uptake and decarboxylation) of the embryonic intestine. Some of the tumors produce a series of hormones and amines which are biologically active and lead to distinct clinical syndromes (functional tumors). Rectal neuroendocrine tumors represent approximately $1.3 \%$ of all the rectal tumors and about $1 / 3$ of the total of the digestive neuroendocrine tumors and are nearly as frequent as those of the small bowel (1). In a recent analysis, the rectum was the second digestive location (34.6\%) after the small bowel (36.5\%) (1). Initially, these tumors were called carcinoids, a term introduced by Oberndorfer in 1907 in order to describe a group of tumors of a better evolution than that of the carcinomas (2). In time, this term was abandoned, being replaced by that of neuroendocrine tumor.

In 2010, the World Health Organization (WHO) established a classification for the neuroendocrine tumors of the digestive system, according to which all tumors are considered malignant with a potential to form metastases. The tumor grading is based on the number of mitoses and on the proliferation index (Ki-67), the tumors being divided into 3 groups:

- G1 <2 mitoses number per 10 high power fields and $\mathrm{Ki}-67<2 \%$;

- G2 2-20 mitoses number per 10 high power fields and $\mathrm{Ki}-67$ 3-20\%;

- G3 >20 mitoses number per 10 high power fields $>20$ and $\mathrm{Ki}-67>20 \%$.

\section{Case Report}

We present the clinical case of a 55-year-old patient who was admitted to the First Clinic of Surgery of the "Prof. Dr. Alexandru Trestioreanu" Bucharest Oncology Institute in December 2018 for rectal bleeding which started 6 months before. At the moment of hospital admission, the findings were the following: liver with the superior border into the 6th right intercostal space and the inferior border at $5 \mathrm{~cm}$ 
underneath the costal margin, of an irregular and increased consistency; and, on the rectal examination one could find the inferior pole of a tumor growth. At the time of admission, the biochemistry and serum tests were normal. The colonoscopy found at $10 \mathrm{~cm}$ from the AO, growing on a distance of $10 \mathrm{~cm}$, a friable vegetative tumor formation which determined marked stenosis of the lumen, but which impeded the passage of the colonoscope, and, from which multiple biopsies were taken. Also, the investigation signalled the presence of a multi-lobed polypus with a wide basis of $2 \mathrm{~cm}$ situated underneath the tumor. The rest of the colon had a normal appearance.

The pathology result: microscopic structure of the ulcerated colic mucosa, with the presence of a malignant proliferation, relatively monomorphic and with a diffuse infiltrative character. It needed immunohistochemistry testing to differentiate between a nondifferentiated carcinoma and a neuroendocrine tumor.

The CT scan shows a stenosing and infiltrating tumor at the upper rectum and rectal-sigmoid junction (Fig. I), with multiple hepatic determinations, disseminated at the level of both hepatic lobes, with the greatest diameter of $37 / 36 \mathrm{~mm}$ (Fig. 2) and subdiaphragmatic increased lymph nodes.

After the tumor board session, it was established that, due to the fourth stage of disease, the therapeutic behavior should be systemic chemotherapy, preceded by colostomy or by Hartmann's procedure, due to the impairment in bowel transit. At the moment of the surgical procedure, the disseminated hepatic metastases were confirmed with the primary tumor at the level of the rectalsigmoid junction expanding into the superior rectum. Hartmann's procedure was performed. The pathology result from the operation was: low differentiated rectal adenocarcinoma with invasion into the muscular, clear resection margins, 8 pericolic lymph nodes invaded, tissue sample from the anterior wall - clear.

The IHC test was compatible with neuroendocrine tumor SYNAPTO positive, CDX2 positive, TTF1 positive, AE1/AE3 positive,



Figure 1. Stenosing and infiltrating tumor at the upper rectum and rectal-sigmoid junction

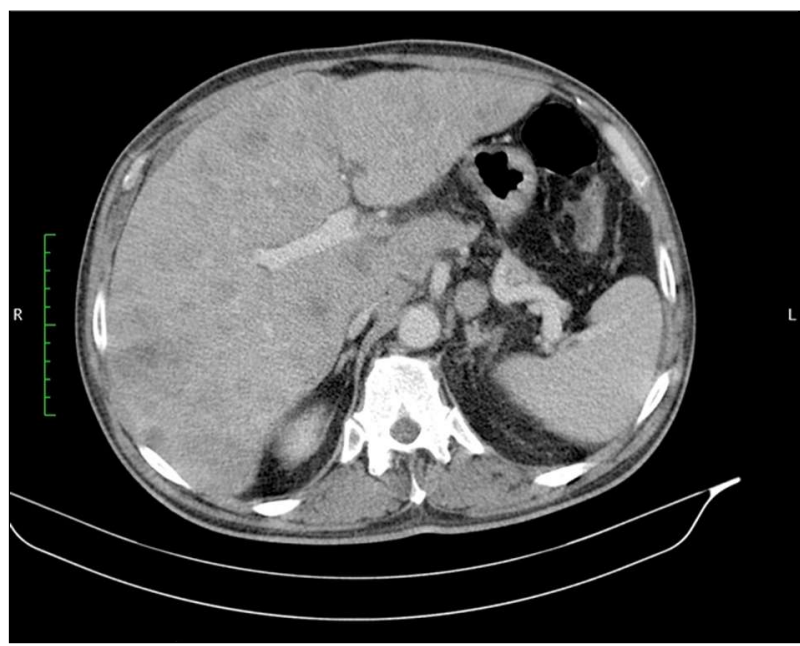

Figure 2. Multiple hepatic metastases

Ki67 75-80\% (G3). Chromogranin A, 5 hydroxy-indole acetic acid and serum serotonin, all within normal values.

After obtaining the IHC testing and the biochemical samples within 30 days from the first admission, the patient is re-admitted to our clinic for pain in the right hypochondrium and weight loss of more than $20 \%$ and bleeding through the anal orifice. TGO of $50 \mathrm{U} / \mathrm{l}$, with the rest of the blood tests within normal limits. The CT scan had the following findings: a left infrahilar lung lymph node with the appearance of either adenomegaly, or a secondary node, small quantity pericarditis, hepatomegaly increased in size from the previous exam, with multiple secondary determinations bigger dimensionally and apparently 
in greater number, rectal stump increased in size, with tumor appearance and iodophilia , adenomegaly above and inferior to the diaphragm, small-medium quantity ascites. Nutritional IV therapy was started for 7 days and painkiller treatment. During the admission, one can notice edema of the inferior left limb, and, after the Doppler exam, the diagnosis of deep thrombophlebitis of the inferior left limb was established, for which anticoagulant treatment was started. Despite the administered treatment, we could notice the worsening of the serum parameters: total bilirubin of $3.70 \mathrm{mg} / \mathrm{dl}$, alkaline phosphatase 297 U/L , GGT 1675 U/L, LDH 208 U/L, TGO $67 \mathrm{U} / \mathrm{L}, \mathrm{TGP} 18 \mathrm{U} / \mathrm{L}$.

Taking into account the IHC testing, a treatment with Etoposide and Cisplatin was started, but the serum samples (the rising bilirubin) did not allow administration of this and a first FOLFOX cure was established with low doses of antiemetics and steroids. Also, Fraxiparin $0.6 \mathrm{ml} \times 2 /$ day. The patient did not undertake the second chemotherapy series.

\section{Discussions}

The majority of the rectal neuroendocrine tumors are lesions of small dimensions. A study found that $79 \%$ were smaller than $1 \mathrm{~cm}$ and only $5 \%$ were bigger than $2 \mathrm{~cm}$. As far as the location is concerned, the majority of the tumors are found in the middle rectum and $74.8 \%$ were found between 5 and $9.9 \mathrm{~cm}$ from the anal verge (2).

The stage of the disease, the ki67 index or the number of mitoses were proven to have a strong predictive value (3), an aspect found also in the case that we presented which had the ki 67 index of $75-80 \%$ (G3) and which had a rapid evolution towards increase in severity. Also, the risk factors for the metastatic disease described in the literature, the tumor size, the invasion into the muscularis propria, the proliferation index, the lymphatic-vascular and perineural invasion (4-6) were all present in the patient presented.

From a clinical point of view, the majority of the patients are asymptomatic, while the tumors are of small dimensions, and, in those patients, finding the tumor is occasional with routine colonoscopy for nonspecific symptoms or during screening programs. In the symptomatic patients, the most frequent symptoms are: rectal bleeding, rectal cramps, the worsening of constipation, or the appearance of a recent constipation pattern and pain due to local tumor invasion or metastases. Carcinoid syndrome is very rare because the tumors per se rarely produce serotonin (2).

The paraclinical and biological testing is useful in establishing the diagnosis and staging: colonoscopy, transrectal ultrasound, CT scan and magnetic resonance, scintigraphy Octreoscan, PET CT, and serum testing.

On colonoscopy, neuroendocrine rectal tumors usually appear as small sessile tumors of the submucosa, enveloped in a mucosa of a pale appearance, as semi-pedicle tumors, ulcerated or simple modifications of the rectal mucosa (depression, erosion, ulceration). In the locally advanced forms, there are no distinct characters from the adenocarcinomas.

Transrectal ultrasound can assess exactly the tumor dimension, the depth of the invasion, the presence of the perirectal increased lymph nodes, which is important for staging. This exploration can diagnose exactly the depth of the lesions of more than $2 \mathrm{~mm}$ (7). Other studies have found a sensibility of 91 and $100 \%$ for transrectal ultrasound in determining the grade of tumor invasion (8).

The role of the CT scan is to detect the regional and distant metastases. MRI is superior in determining the liver metastases and can be used where there is no certainty regarding the nature of the lesions identified on CT scan (4).

The scintigraphy scan (Octreoscan) uses radio-marked somatostatin analogues in order to detect the receptors for somatostatin .The method is less useful in the identification of the primary tumor, but in patients with metastases it allows us to chose a certain treatment (9).

PET CT scan is useful in staging the tumors of a high grade/ low differentiated grade which do not exhibit the somatostatin 
receptors (9). Octreoscan and PET CT scan are useful in staging if one suspects residual disease or metastatic disease (4).

Serum tests, determining chromogranin A has a limited use in rectal neuroendocrine tumors without metastases, but it can be used in order to monitor patients with metastatic disease. As little rectal neuroendocrine tumors produce serotonin , the value of the 5 hydroxyindole acetic acid in the diagnosis is used on a lower scale.

In order for a precise diagnosis, it is absolutely necessary to perform the IHC tests which bring supplementary data regarding tumor aggressiveness, by establishing the tumor grade, with the number of mitoses and the proliferation index (Ki-67 index). The presence of a $\mathrm{Ki}-67>20 \%$ indicates a G3 tumor with a higher grade of aggressiveness. In the case presented, the paraclinical exploration indicated a locally advanced neuroendocrine tumor with multiple liver metastases and a very high aggressiveness with a ki 67 index of $75-80 \%$.

As far as the treatment is concerned, the tumor dimension is the most important predictor of tumor behavior and is the main factor in order to select the option for surgical treatment.

Therefore, tumors of less than $1 \mathrm{~cm}$ due to the low risk of lymphatic dissemination and distant metastases are recommended endoscopic excision in the limits of the oncologic safety, and if this is not achieved, they have to be reevaluated postoperatively and supplementary treatment has to be applied (6). Tumors less than $10 \mathrm{~mm}$ with a high risk factor (the invasion of the muscular layer, the lymphatic vascular invasion, or the high mitotic index) are less frequent (1). Despite all this, in a series of 37 patients with tumors less than $1 \mathrm{~cm}$ in diameter, one patient $(2.7 \%)$ had an invasion into the muscular layer, 3 patients (8.1\%) presented with lymphatic vascular invasion and 5 patients $(13.5 \%)$ had a mitotic index of $\geq 2 / 50 \mathrm{HPF}$ (not on $10 \mathrm{HPF}$ ) (1). If the pathology diagnosis was established in a preoperative biopsy, this high-risk cases should be treated with radical resection and lymphatic dissection (1). Transanal endoscopic microsurgery can be an option in well-selected cases, but followed by a more attentive follow up.

For the tumors of dimensions between 1 and $2 \mathrm{~cm}$, due to the higher risk of dissemination, there are several discussions involving the surgical treatment .Some studies show that tumors of more than $1.4 \mathrm{~cm}$ already have a dissemination risk (10). Nevertheless, the recommendation of the European Society for Neuroendocrine Tumors is that tumors of less than $2 \mathrm{~cm}$ with a low mitotic index, without any invasion into the muscularis propria and without increased lymph nodes be resected via endoscopy (4). Tumors less than $15 \mathrm{~mm}$ which do not have an invasion into the muscularis propria or a lymphatic invasion can behave similarly to tumors of less than 10 $\mathrm{mm}$ and could initially be treated via endoscopy, with the marking of the endoscopic surgery site. If the pathology examination finds lymphatic vascular invasion or a high mitotic index in the sample, then further reexcision can be necessary or a radical surgical intervention with lymphatic dissection can be requested, due to the risk of lymph node metastases (1).

According to the NCCN guidelines version 4.2018-07,2019, for the tumors of more than 2 $\mathrm{cm}$ the treatment is surgical resection with colorectal anastomosis or abdominal perineal resection and loco-regional lymph node dissection. In patients with intense and recurrent symptomatology caused by the primary tumor or in those with secreting tumors and with clinical manifestations of the carcinoid syndrome, one may perform the resection of the primary tumor even if incomplete, but with the exeresis of at least $90 \%$ of the tumor mass. This attitude even if of controversy, can be applied in well-selected cases. The surgical resection or ablative procedures of the liver metastases was used either with a curative intent or to reduce the size of the tumor masses. In the case that we presented, after the tumor board session, due to the fact that the multiple liver lesions were disseminated, there was no therapeutic surgical solution and it was decided that systemic chemotherapy 
should be done preceded by the resection of the primary tumor as it was stenosing and bleeding.

Systemic chemotherapy is recommended for G3 patients and is rarely used in G1 and G2. The radionuclide therapy of the peptic receptors is recommended for patients with receptors positive for somatostatin. This treatment can be used in metastatic neuroendocrine non-operable lesions with receptors positive for somatostatin (4). Alpha interferon also seems to have an antisecretory and antiproliferative effect, both in secreting as in non-secreting $(11,12)$. In the case presented, we tried to administer a treatment with Etoposide and Cisplatin, but the onset of hepatic failure did not allow the administration of the series and instead, we administered a first cure of FOLFOX treatment with reduced dosage of antiemetic and steroid.

\section{Conclusions}

1. Even though neuroendocrine rectal tumors are generally small and well-differentiated with a rather good prognosis, there are forms with bigger dimensions, metastases, and severe prognosis;

2. The stage of the disease and the ki-67 index have a prognostic importance;

3. In order to establish the diagnosis and the aggressiveness IHC testing is mandatory.

\section{Conflicts of Interest}

The authors declare no conflicts of interests.

\section{Ethics Approval}

All procedures performed were in accordance with the ethical standards of the 1964 Helsinki Declaration and its later amendments.

\section{References}

1. Updating the management of patients with rectal neuroendocrine tumors. Louis de Mestier, Hedia Brixi, Rodica Gincul, Thierry Ponchon, Guillaume Cadiot. Endoscopy. 2013;45(12):1039-1046.

2. Rodrigues A, Castro-Poças F, Pedroto I. Neuroendocrine Rectal Tumors: Main Features and Management. GE Port J Gastroenterol. 2015;22(5): 213-220.

3. Jann H, Roll S, Couvelard A, Hentic 0, Pavel M, Müller-Nordhorn J, et al. Neuroendocrine tumors of midgut and hindgut origin: tumor-nodemetastasis classification determines clinical outcome. Cancer. 2011; 117(15):3332-41.

4. Ramage JK, De Herder WW, Delle Fave G, Ferolla P, Ferone D, Ito T, et al. ENETS Consensus Guidelines Update for Colorectal Neuroendocrine Neoplasms. Neuroendocrinology. 2016;103(2):139-43.

5. McDermott F, Heeney A, Courtney D, Mohan H, Winter D. Rectal carcinoids: a systematic review. Surg Endosc. 2014;28(7):2020-6.

6. Mestier L, Brixi H, Gincul R, Ponchon T, Cadiot G. Updating the management of patients with rectal neuroendocrine tumors. Endoscopy. 2013; 45(12):1039-46.

7. Kobayashi K, Katsumata T, Yoshizawa S, Sada M, Igarashi M, Saigenji K. Indications of endoscopic polypectomy for rectal carcinoid tumors and clinical usefulness of endoscopic ultrasonography. Dis Colon Rectum. 2005;48(2):285-91.

8. Ishii N, Horiki N, Itoh T, Maruyama M, Matsuda M, Setoyama T. Endoscopic submucosal dissection and preoperative assessment with endoscopic ultrasonography for the treatment of rectal carcinoid tumors. Surg Endosc. 2010;24(6):1413-9.

9. Mandair D, Caplin Martyn E. Colonic and rectal NET's. Best Pract Res Clin Gastroenterol. 2012;26(6):775-89.

10. Park CH, Cheon JH, Kim JO, Shin JE, Jang BI, Shin SJ. Criteria for decision making after endoscopic resection of well-differentiated rectal carcinoids with regard to potential lymphatic spread. Endoscopy. 2011;43(9):790-5.

11. Anthony LB, Strosberg JR, Klimstra DS, Maples WJ, O'Dorisio TM, Warner RRP. The NANETS consensus guidelines for the diagnosis and management of gastrointestinal neuroendocrine tumors (nets): well-differentiated nets of the distal colon and rectum. Pancreas. 2010;39(6):767-74.

12. Koizumi M, Onda M, Tanaka N, Seya T, Yamada T, Takahashi Y. Antiangiogenic effect of octreotide inhibits the growth of human rectal neuroendocrine carcinoma. Digestion. 2002;65(4):200-6. 